Acta vet. scand. $1978,19,569-573$.

From the National Veterinary Institute and the Department of Pathology, Veterinary College of Norway, Oslo.

\title{
VIRUS ENTERITIS OF MINK \\ A SCANNING ELECTRON MICROSCOPIC INVESTIGATION
}

\author{
By \\ Thor Landsverk and Knut Nordstoga
}

\begin{abstract}
LANDSVERK, THOR and KNUT NORDSTOGA: Virus enteritis of mink. A scanning electron microscopic investigation. Acta vet. scand. $1978,19,569-573$. - Advanced lesions in the jejunal mucosa in virus enteritis of mink were studied by scanning electron microscopy. The changes were found to be in good accordance with those observed in the light microscope, and included ballooned degeneration of enterocytes, epithelial desquamation, the occurrence of fibrinous pseudomembranes, atrophy or total loss of villi; partially atrophied villi were frequently fused. In some areas there were incipient regenerative processes, including proliferation of ballooned cells which covered the luminal surface of the damaged jejunal wall.
\end{abstract}

virus enteritis; enterocytes; ballooned degeneration; mink; scanning electron microscopy.

Virus enteritis of mink (VEM) was first described in Canada (Schofield 1949) and during subsequent years reported from several other countries (Gorham \& Hartsough 1954, Knox 1958, Kangas 1962, Kull 1966). In this country VEM was first recognized in 1956 (Svenkerud \& Ilaug, unpublished), and during the last 2 decades several outbreaks of VEM have occurred in various districts in Norway. Clinically the disease is characterized by anorexia and loose stool, frequently mixed with fibrinous casts and mucus.

Microscopic lesions in the intestine include the presence of "ballooned" epithelial cells, a finding which is considered to be of definite diagnostic value, desquamation of epithelium, and shortened villi (Schofield, Myers \& Fritz 1959, Krunajević 1970, Reynolds 1970, Johannsen et al. 1975). While the light microscopic intestinal lesions in VEM are well established, and Kruna- 
jevic has described alterations in intestinal epithelium observed in the transmission electron microscope, the present authors are unaware of any previous report based on scanning electron microscopic (SEM) studies.

\section{MATERIALS AND METHODS}

Two males and one female Standard mink were obtained from a farm where VEM had been diagnosed by clinical and pathological examination. The animals used had shown characteristic clinical signs of VEM for about a week. One healthy Standard male mink was obtained from the Research Station for Fur-Bearing Animals, Heggedal, and used as control. Obtaining of specimens was performed during anesthesia with pentobarbital sodium intraperitoneally; the abdomen was opened and Karnovsky's fixative (Karnovsky 1965) was injected into the intestinal lumen. Thereupon the intestines were cut from the mesenteric attachment and immediately opened and submersed in the fixative. After at least one month of fixation, specimens were taken from the following sites, given in $\mathrm{cm}$ posterior to pylorus: $5,15-25,40,60-80,100-110$. The total lengths of the fixed intestines were: 120 (control), $140\left(\sigma^{\star}\right), 110(q)$ and $120\left(\sigma^{*}\right) \mathrm{cm}$, respectively. Specimens for light microscopy were dehydrated in ethanol, equilibrated in xylol and embedded in paraffin; sections were stained with hematoxylin and eosin (HE) and periodic acid-Schiff (PAS). Specimens for SEM were washed in distilled water, dehydrated in ethanol, equilibrated in acetone and dried in a critical point dryer with carbon dioxide as the transitional fluid. The dried specimens were attached to metal stubs with colloidal silver, coated with gold in a vaccuum evaporator, and the coated samples were examined with a Jeol 50A scanning electron microscope with an accelerating voltage of $10-15 \mathrm{kv}$. Photographs were recorded on Polaroid Type 52 film.

\section{RESULTS}

The control animals exhibited normal intestinal mucosa, as judged by SEM, with relatively short finger-like villi in anterior and posterior jejunal portions (Fig. 1) and longer, leaf- or finger-shaped villi in middle parts of jejunum. By light microscopy the villi were found to be covered with a columnar epithelium; they had a slight cellular infiltration (Fig. 2). 
Figure 1. Scanning electron micrograph of control animal, $5 \mathrm{~cm}$ posterior to pylorus. Normal finger-shaped villi with bulged cells. $\times 150$.

Figure 2. Area adjacent to Fig. 1. Normal villi with columnar enterocytes along villi and crypts. Lamina propria has a moderate mononuclear infiltration. $\mathrm{HE} \times \mathbf{1 5 0}$.

Figure 3. Scanning electron micrograph of VEM-diseased animal, $5 \mathrm{~cm}$ posterior to pylorus, showing loss of villi with flattened mucosal surface, ballooned epithelial cells and ulcerated areas (small arrows). Some areas are covered with a necrotic or fibrinous material (large arrows). $\times 150$.

Figure 4. Area adjacent to Fig. 3 showing ballooned superficial enterocytes, dilated crypts (D) sometimes containing necrotic cells (N) ; other crypts have swollen epithelial cells. Proliferation of mononuclear cells in lamina propria. $\mathrm{HE} \times 150$.

Figure 5. Scanning electron micrograph of area adjacent to Fig. 3 showing ballooning and stretching (arrows) of enterocytes; an ulcerated area is also visible (U). $\times 400$.

Figure 6. Scanning electron micrograph of VEM-diseased animal, $5 \mathrm{~cm}$ posterior to pylorus, showing fusion of shortened villi with ballooning of apical enterocytes. $\times 300$.

Figure 7. Scanning electron migrocraph of VEM-diseased animal, $15 \mathrm{~cm}$ posterior to pylorus. Partial atrophy of villi and conspicuous ballooning of apical enterocytes. $\times 300$.

Figure 8. Scanning electron micrograph of VEM-diseased animal, $25 \mathrm{~cm}$ posterior to pylorus, showing apex of a villus in which elevated ridges (small arrows) can be seen between individual cells. Incipient superficial erosions are indicated by large arrows. $\times 1000$.

Figure 9. Scanning electron micrograph of VEM-diseased animal, $40 \mathrm{~cm}$ posterior to pylorus. There is partial fusion of villi and deep furrows between groups of fused villi (arrows). $\mathrm{N}$ indicates a necrotic or fibrinous material. $\times 150$.

Figure 10 . Area adjacent to Fig. 9 showing extensive ballooning of enterocytes on the surface of atrophied villi and in some crypts. Other crypts are dilated (D) or hypercellular (arrows), the latter pattern indicating regeneration. $\mathrm{HE} \times 150$.

Figu re 11. Scanning electron micrograph of VEM-diseased animal, $70 \mathrm{~cm}$ posterior to pylorus, with villous atrophy and ulcerated apical areas (arrows). $\times 150$.

F i g u re 12 . Scanning electron micrograph of VEM-diseased animal, $80 \mathrm{~cm}$ posterior to pylorus. There are moderate atrophy of the villi which are covered with strands of a fibrinous material. $\times 50$. 

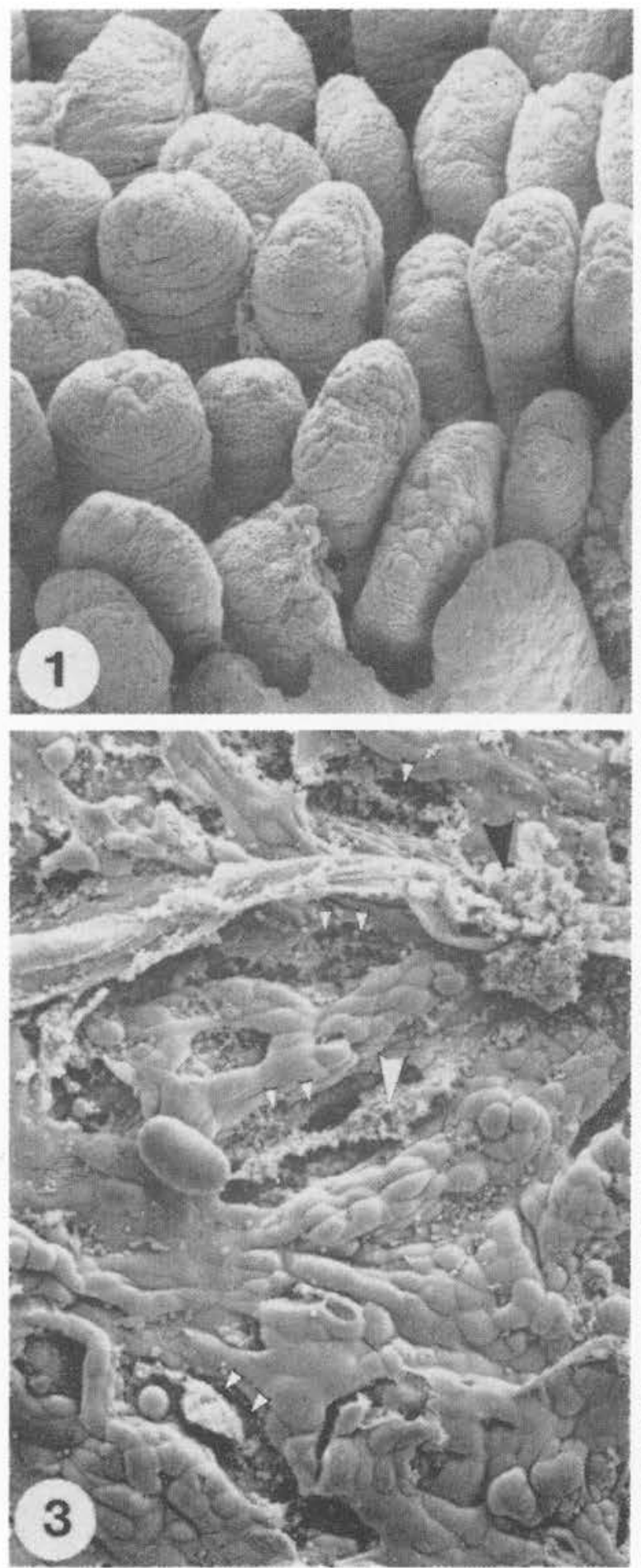

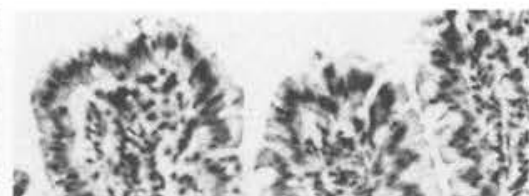

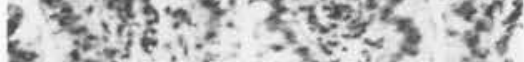

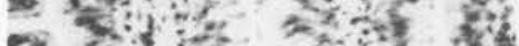

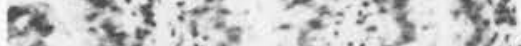

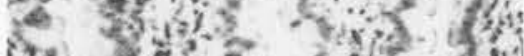

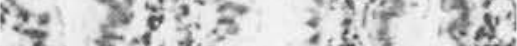
7 5

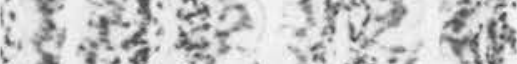
1.4. $43,2=5$

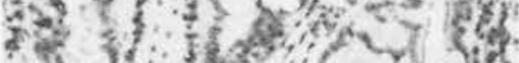

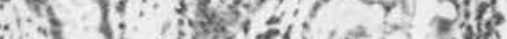

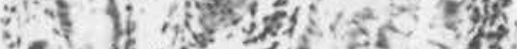
if if 2 की

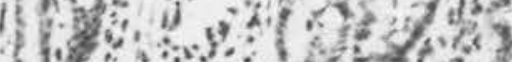

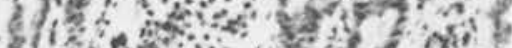
1.8.

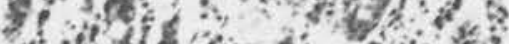

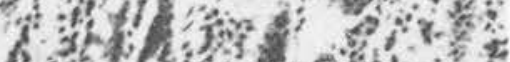

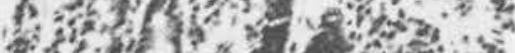

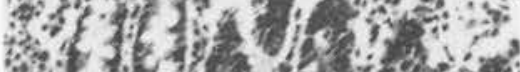

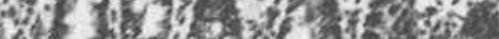

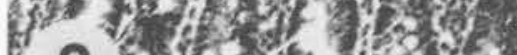

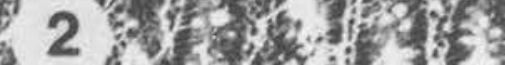
2. 2 s.

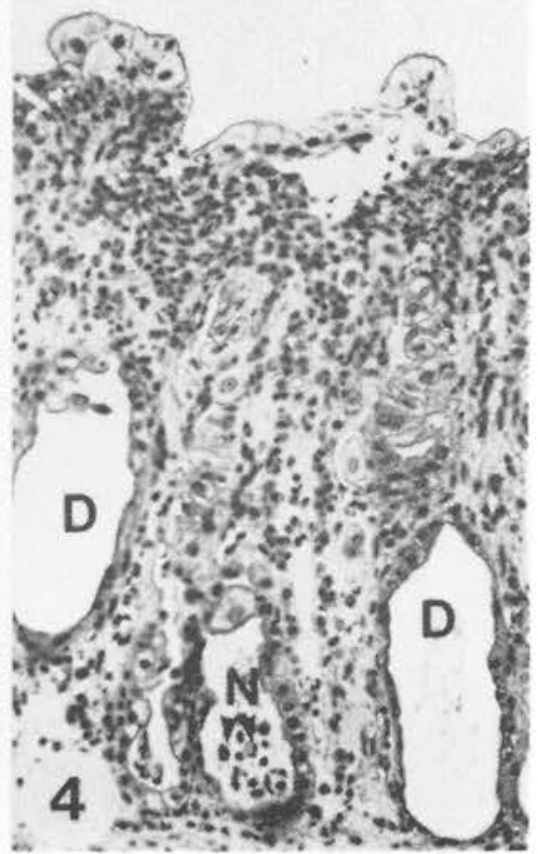



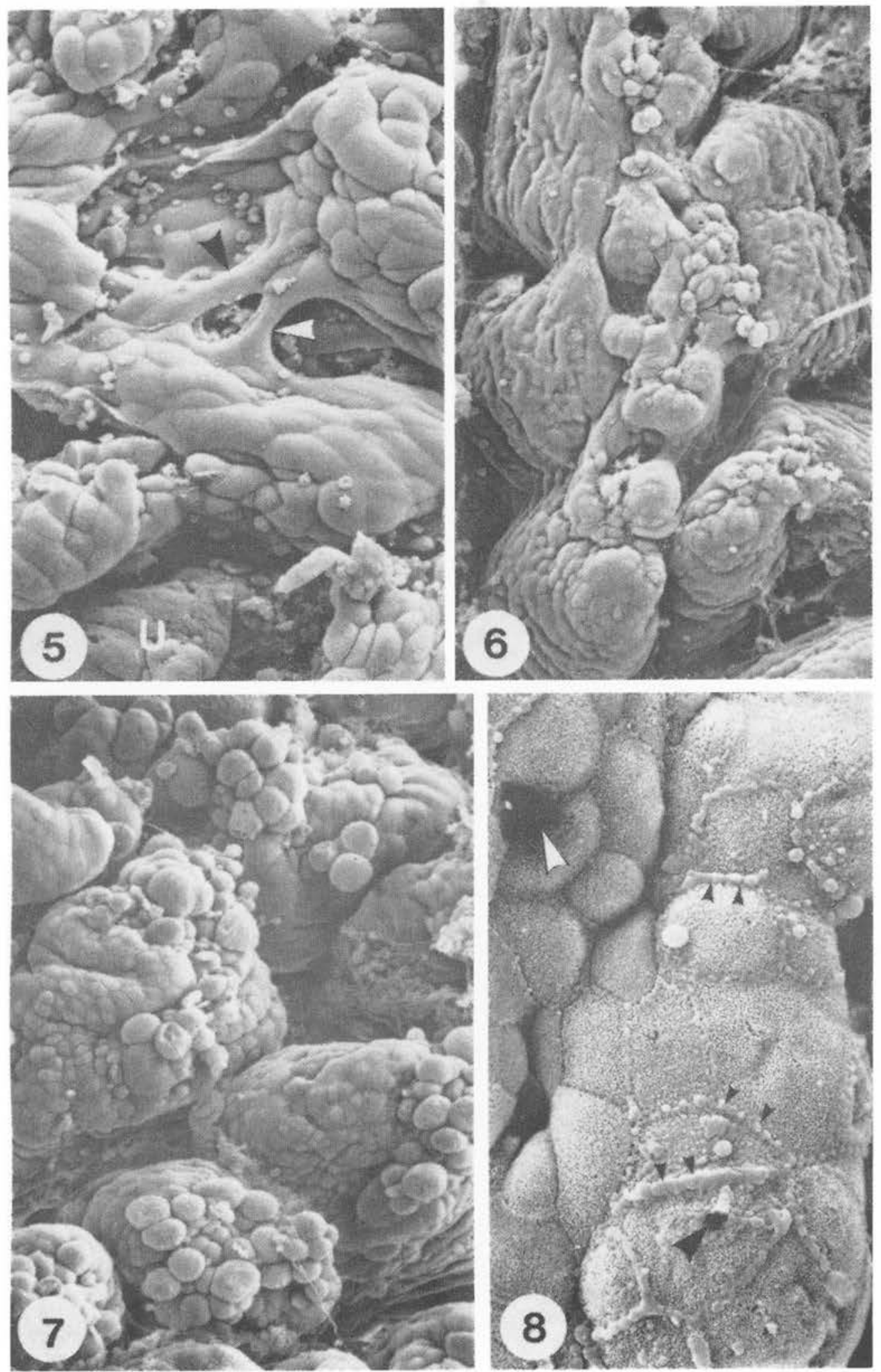

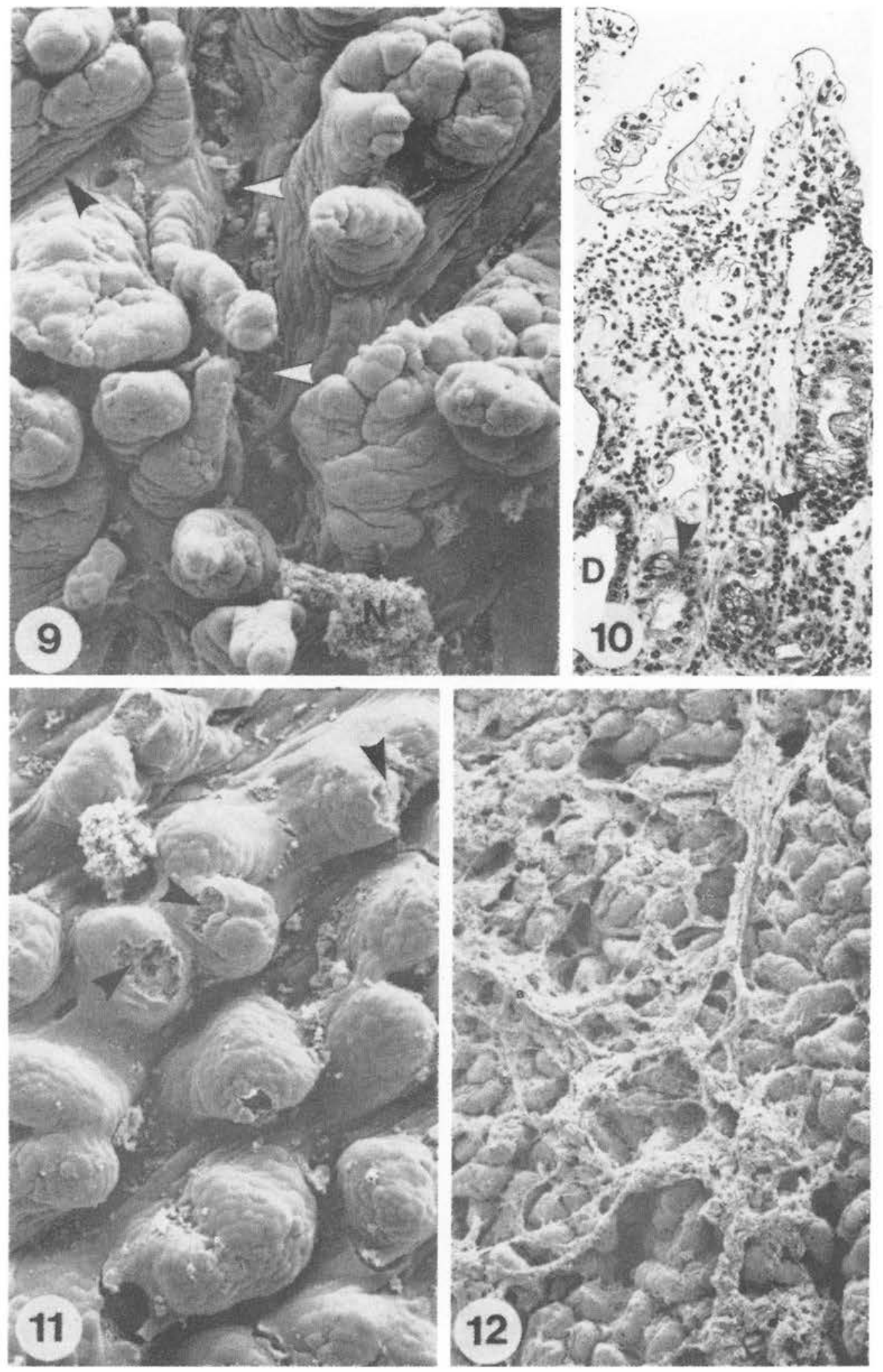
By SEM of the diseased animals the small intestinal mucosa displayed widespread atrophy and sometimes loss of villi (Figs. $3,5,6,7,9,11)$. Partially atrophied villi frequently showed fusion (Figs. 6, 9). The enterocytes were swollen, often to a conspicuous degree, forming "balloons"; some areas were denuded (Figs. 3, 5, 11). In some enterocytes at tips of villi elevated ridges between individual cells were seen (Fig. 8). Portions of mucosa were covered by a necrotic or fibrinous layer (Figs. 3, 9, 12).

By light microscopy of the diseased animals the intestinal villi showed extensive atrophy with ballooning degeneration of enterocytes (Figs. 4, 10), corresponding to the changes seen by SEM. Lamina propria had a varying proliferation of mononuclear leukocytes. The crypts were frequently dilated with a flattened epithelium, or showed prominent swelling and sometimes also hyperplasia of epithelial cells.

\section{DISCUSSION}

Our investigation disclosed that in later stages of VEMdiseased animals there was extensive degeneration and desquamation of enterocytes, together with the formation of fibrinous pseudomembranes which covered the damaged intestinal surface. These observations correspond in great parts to the descriptions of others, based on light microscopic and transmission electron microscopic studies (Schofield 1949, Myers \& Fritz 1959, Krunajević 1970, Reynolds 1970, Johannsen et al. 1975), although it seems that the SEM technique is especially well suited to visualize the lesions occurring in intestinal mucosa in association with VEM.

Fusion of partially atrophied villi was a very common finding in our material, associated with replacement of enterocytes from preserved epithelial cells in the crypts. Similar phenomena are also described in other species in connection with profound damage of intestinal mucosa, such as in transmissible gastroenteritis in swine and experimental corona virus infection in calves (Waxler 1972, Olson et al. 1973, Mebus et al. 1975). We interpret this pattern as an expression of regeneration and conclude that such cells are also present in the regenerative phase. This is in contrast to the investigation of Krunajevic, who did not observe ballooned cells in this stage of involvement. Johann- 
sen et al. found, however, that degenerative and regenerative processes may be present in adjacent areas, an observation that agrees with our study.

\section{ACKNOWLEDGEMENTS}

We wish to thank the Department of Anatomy, Dental Faculty, University of Oslo for letting us use its scanning electron microscope, and S. Stølen, engineer, for excellent operation of the same. We are also indebted to K. R. Blystad, district veterinarian, for helping us with obtaining specimens from diseased animals.

\section{REFERENCES}

Gorham, J. R. \& G. R. Hartsough: Virus diseases of mink. Proc. 91st Ann. Meeting, Amer. vet. med. Ass. 1954, 244-247.

Johannsen, U., R. Kokles \& A. Tohtz: Untersuchungen zur Diagnostik der Virusenteritis der Nerze. 2. Mitt. Pathomorphologie der Erkrankung. (Study into diagnosis of virus enteritis in mink. 2nd communication. Pathomorphology of the disease). Mh. Vet.Med. 1975, 30, 274-278.

Kangas, J.: Minkkien virusripulin esiintyminen Suomessa. (Viral enteritis of mink in Finland.) Finsk Vet.-T. 1962, 68, 261-269.

Karnovsky, M. J.: A formaldehyde-glutaraldehyde fixative of high osmolality for use in electron microscopy. J. Cell Biol. 1965, 27, 137A-138A.

Knox, B.: Virus enteritis hos mink konstateret for første gang i Danmark. (Virus enteritis in mink observed for the first time in Denmark). Medlemsbl. danske Dyrlægeforen. 1958, 41, 727-730.

Krunajević, T.: Experimental virus enteritis in mink. A pathologicanatomical and electron microscopical study. Acta vet. scand. 1970, 11, Suppl. 30.

Kull, K.-E.: Virusenterit i Sverige. (Virus enteritis in Sweden). Våra pälsdjur 1966, 8, 331.

Mebus, C. A., L. E. Newman \& E. L. Stair: Scanning electron, light and immunofluorescent microscopy of intestine of gnotobiotic calf infected with calf diarrheal coronavirus. Amer. J. vet. Res. 1975, $36,1719-1725$.

Myers, W. L. \& T. E. Fritz: Histopathologic changes in virus enteritis of mink. Canad. J. comp. Med. 1959, 23, 246-249.

Olson, D. P., G. L. Waxler \& A. W. Roberts: Small intestinal lesions of transmissible gastroenteritis in gnotobiotic pigs: A scanning electron microscopic study. Amer. J. vet. Res. 1973, 34, 12391245.

Reynolds, H. A.: Pathological changes in virus enteritis of mink. Canad. J. comp. Med. 1970, 34, 155-163.

Schofield, F. W.: Virus enteritis in mink. N. Amer. Vet. 1949, 30, 651654. 
Waxler, G. L.: Lesions of transmissible gastroenteritis in the pig as determined by scanning electron microscopy. Amer. J. vet. Res. $1972,33,1323-1328$.

\section{SAMMENDRAG}

Virus-enteritt hos mink. En skanning elektron-mikroskopisk undersøkelse.

Langt framskredne forandringer i tynntarmen ved virus-enteritt hos mink ble studert ved skanning elektron-mikroskopi. De ble funnet å være i god overensstemmelse med dem som kan observeres i lysmikroskopet, og inkluderte ballonerende degenerasjon i enterocyttene, deskvamasjon av epitel, og atrofi eller totalt svinn av villi samt forekomst av fibrinøse pseudomembraner; delvis atrofiske villi var ofte sammenvokste. I enkelte områder var det begynnende regenerative forandringer; disse inkluderte proliferasjon av ballonerte celler som delvis dekket den luminale overflaten av tarmen.

(Received May 22, 1978).

Reprints may be requested from: T. Landsverk, the National Veterinary Institute, P. O. Box 8156, Oslo Dep., Oslo 1, Norway. 